\title{
Comparing children's care work across Majority and Minority worlds
}

Book or Report Section

Accepted Version

Evans, R. and Becker, S. (2018) Comparing children's care work across Majority and Minority worlds. In: Twum-Danso Imoh, A., Bourdillon, M. and Meichsner, S. (eds.) Global Childhoods beyond the North-South Divide. Palgrave, pp. 231253. ISBN 9783319955421 doi: https://doi.org/10.1007/978-3319-95543-8_12 Available at https://centaur.reading.ac.uk/77364/

It is advisable to refer to the publisher's version if you intend to cite from the work. See Guidance on citing.

To link to this article DOI: http://dx.doi.org/10.1007/978-3-319-95543-8_12

Publisher: Palgrave

All outputs in CentAUR are protected by Intellectual Property Rights law, including copyright law. Copyright and IPR is retained by the creators or other copyright holders. Terms and conditions for use of this material are defined in the End User Agreement.

\section{www.reading.ac.uk/centaur}

\section{CentAUR}


Central Archive at the University of Reading

Reading's research outputs online 


\title{
Beyond Binaries: Exploring Children's Lives across Worlds \\ Editors: Afua Twum-Danso Imoh, Michael Bourdillon, and Sylvia Meichsner
}

Title: Comparing children's care work across Majority and Minority worlds Authors: Ruth Evans (University of Reading) and Saul Becker (University of Sussex)

\begin{abstract}
(150 words)
Comparative qualitative methodologies that investigate children's lives in sharply contrasting socio-economic, political and welfare contexts are relatively unusual. Yet within an increasingly interdependent globalised world, comparative research and dialogue across binaries seems ever more important. In this chapter, we critically reflect on global conceptualisations of young caregiving and discuss the methodological and ethical challenges that arose in our comparative study of children caring for a parent/relative living with HIV in Tanzania and the UK. We discuss the potential problems and benefits of using the term "young carer" and suggest that levels of support and recognition of children's caring roles in particular countries do not follow a simple Majority/Minority world binary, but rather reveal a more complex picture. We argue that developing global perspectives that work across geographical, linguistic and disciplinary boundaries can facilitate greater understanding of the commonalities and diversities of children's caring lives globally.
\end{abstract}

\section{Contact details:}

Dr. Ruth Evans

Associate Professor in Human Geography

Participation Lab Leader

Department of Geography \& Environmental Science

University of Reading

Whiteknights PO Box 227

Reading RG6 6AB, UK

Email: r.evans@reading.ac.uk

Twitter:@DrRuth_Evans

https://blogs.reading.ac.uk/deathinthefamilyinsenegal/

https://blogs.reading.ac.uk/participation-lab 


\section{Comparing children's care work across Majority and Minority worlds}

\section{Introduction}

Comparative qualitative methodologies that investigate children's lives across MajorityMinority binaries are relatively unusual. Yet dialogue across worlds, which often contrast sharply regarding the socio-cultural, economic, political and welfare context, is increasingly important in order to understand the complexity of children's lives globally. In this chapter ${ }^{1}$, we discuss the potential and challenges of conducting comparative research on children's care work across Majority and Minority worlds ${ }^{2}$ and propose a number of ways to further global conceptualisations.

We first discuss children's care work in the context of Sub-Saharan Africa, drawing on Becker's (2007) and Leu and Becker's (2017) classifications of in-country responses to children who are carers. We reflect on the methodological and ethical challenges that emerged in our comparative qualitative study ${ }^{3}$ of the experiences, needs and resilience of children caring for a parent or relative living with HIV in Tanzania and the UK. We critically reflect on global conceptualisations of young caregiving and highlight key similarities and differences in children's caring activities across worlds. We then reflect on the potential problems and benefits of the use of the term "young carer" and highlight the value of Evans and Skovdal's (2015) modified definition that encompasses the diversity of children's caring roles in Majority world contexts. Levels of support and recognition of children's caring roles in particular countries do not follow a simple Majority/Minority world binary, but rather reveal a more complex picture, as Leu and Becker (2017) suggest.

\section{Children's care work in Sub-Saharan Africa}

Research on children's care work globally has burgeoned in the last three decades, from the pioneering studies led by Saul Becker and colleagues in the 1990s (Becker et al, 1998), in collaboration with key practitioners advocating for legal and social policy recognition and support for "young carers" in the UK. Studies of young caregiving in the US and Australia have largely supported the findings of UK studies, with regard to the extent, nature and outcomes of children's care work in families affected by disability, mental health and substance misuse (Pursal et al, 2012; National Alliance for Caregiving, 2005). Yet there is often little dialogue between researchers working on young carers in the Minority world and those investigating children's work, including unpaid domestic and care work, in Majority world contexts.

The involvement of children and youth in work represents a key feature of many childhoods in the Majority world that conflicts with universal ideals of childhood and dominant children's rights discourses (Evans, 2010). In many societies in Sub-Saharan Africa, sociocultural norms and levels of poverty mean that most children are expected to engage in paid and unpaid work from an early age as part of the household economy. Such responsibilities are usually valued as part of children's informal education and socialization in the family and community. Researchers to date have conceptualized these activities undertaken by children predominantly as familial and domestic responsibilities or social reproductive work (Abebe and Kjørholt, 2009) rather than as "young caregiving". International development agencies usually draw on discourses of "child labour", which has been the focus of considerable global concern since the 1990s (ILO, 2014). Yet the ILO definition of "children in employment" and "child domestic work" excludes work undertaken in the child's own household, rendering 
children's, especially girls', unpaid care work within the family invisible (Evans and Skovdal, 2015).

Many have argued that dominant children's rights discourses, which have been globalised through UN agencies and international development policy and practice, social work, psychology and other disciplines, are rooted in idealised Minority world notions of childhood (Boyden, 1997; Ribbens McCarthy et al., 2017). In many African countries, family and community members and NGO staff highlight the importance of recognising children's reciprocal responsibilities to their families and communities, as well as their rights. Such responsibilities are reflected in the African Charter on the Rights and Welfare of the Child (1990), which was developed in response to disenfranchisement with the universalist and individualistic nature of the UN rights discourse.

This socio-cultural recognition of children's contribution to the family and community might be expected to lead to greater acceptance of the need to support young carers in legislation, policy and practice in African countries. Becker's (2007) typology of levels of awareness and responses to young carers at the global level categorises the UK, USA, Australia and SubSaharan African responses from "advanced" and "intermediate" to "preliminary" and "emerging". "Advanced" (the UK is the only country identified here) is characterised by widespread awareness and recognition of young carers among public, policy makers and professionals; extensive and reliable research base; specific legal rights (national); extensive codes and guidance for welfare professionals and national and local strategies; multiple dedicated services and interventions nationwide. Sub-Saharan African countries' responses were categorised as "emerging", with an embryonic awareness of young carers as a distinct social group within the 'vulnerable children' population. Becker (2007) argues that local context is critical in determining social policy and service development responses at the national level, but that there is also policy transfer across geographical boundaries.

Furthermore, he observes researchers and policymakers in Minority world can learn from the experiences of young carers in the Majority world and points to new directions for research, such as using the concept of resilience as well as vulnerability (Becker, 2007). This was an important point of departure for our comparative study of young carers in families affected by HIV in Tanzania and the UK.

Sub-Saharan Africa was the only region from the Majority world included in the typology, largely due to the paucity of published material and knowledge about policy and practice responses to young carers elsewhere. The scale of the HIV epidemic in Eastern and Southern Africa since the 1980s and recognition of the significance of informal care provided by families and communities for sick and dying relatives has led to a growing body of literature exploring children's care work in this context (Robson et al, 2006; Bray, 2009; Evans, 2012; Skovdal, 2011). These studies have, in some cases, explicitly engaged with concepts and approaches originally developed in Minority world research with young carers, despite sharply diverging socio-cultural, economic and welfare contexts (Robson and Ansell, 2000; Bauman et al, 2006; Evans and Becker, 2009; Skovdal and Andreoulis, 2011).

Leu and Becker (2012) updated classification of in-country responses to children who are carers builds on Becker's (2007) typology, with analysis of further Minority world countries, with Sub-Saharan Africa again included as the only Majority world region. The level of responses ranges from 1 "Incorporated/ sustainable" which no country has yet achieved, to 7 "No response" for all other countries not included in the classification, characterised as no 
apparent awareness or policy response to young carers as a distinct social group. Sub-Saharan Africa is characterised as level 5 'emerging', alongside Belgium, Ireland, Italy, Switzerland, the Netherlands and the United States. This level is characterised by growing public or specialist awareness and recognition of young carers; a small but growing research base; no specific legal rights but other laws may be applicable or relevant; no specific services or interventions for young carers, but other services might be applicable (Leu and Becker, 2012, p.22).

More fine-grained analysis is needed of specific country responses in Sub-Saharan Africa, in line with the analysis of Minority world countries. There is likely to be considerable diversity of responses among Sub-Saharan African countries; greater recognition of "young carers" might be expected in Ethiopia, Kenya, Tanzania, Uganda, Zambia, Zimbabwe and South Africa, for example, given the scale of the HIV epidemic, where many children have been drawn into significant caring roles. Evidence suggests that the experiences of young carers in HIV-affected households may also differ to those of other young carers. In South Africa, for example, quantitative evidence suggests that higher levels of care work among adolescents were significantly associated with living in a home with an AIDS-sick relative and with missing school and experiencing problems concentrating at school (Cluver et al, 2012). While those living in homes with other non-AIDS-related sickness were also more likely to miss or drop out of school, they had no more problems concentrating than young people in healthy homes. This suggests that it is anxiety about their parent's illness that distinguishes young people's caring roles in HIV-affected households from those of other young carers, with negative impacts on their educational performance (Cluver et al, 2012).

Alongside differences in policy responses and the scale of the HIV epidemic, greater policy and practice recognition of children's care work may be evident in African countries affected by conflict, displacement or other epidemics such as Ebola, where many children may have been orphaned, have a family member who is disabled or have become separated from parents or other adult caregivers, such as in northern Uganda, the Democratic Republic of Congo, South Sudan, Sierra Leone, Liberia, Guinea and so on. Comparative research between African countries with contrasting social protection systems and care needs could provide interesting findings about commonalities and differences in children's care work in Majority world settings.

Similarly to Sub-Saharan Africa, in-country responses to caregiving children in other Majority world regions are likely to be equally diverse, from "no response", "awakening", "emerging" to potentially the higher levels of "preliminary", "intermediate" or "advanced" (Leu and Becker, 2012). Indeed, rather than Majority world responses being regarded in a hierarchical relation to Minority world responses, the responses of several European countries have much in common with Sub-Saharan African country responses (Leu and Becker, 2012). Hence, living in Belgium, Ireland, Italy, Switzerland, the Netherlands, or in the US, does not necessarily mean that the response to caregiving children is any more "advanced" in terms of policy, legislation or rights than in Kenya, for example.

Bauman et al's (2006) study on young carers in families affected by HIV in Zimbabwe and the US and our own cross-national research on children caring for parents and relatives with HIV in Tanzania and the UK (Evans and Becker, 2009) explicitly sought to compare children's care work across Majority-Minority worlds. In the next section, we reflect on methodological and ethical challenges we encountered in working across worlds. 


\section{Challenges in researching children's care work across Majority-Minority binaries}

Our comparative study developed from our combined interests and research experience in Tanzania and the UK. The research sought to compare children's caring experiences in Tanzania, a country with high HIV prevalence, high levels of national poverty and limited formal social safety nets, to those of children in the more affluent context of the UK, where $\mathrm{HIV}$ affects a much smaller proportion of the population and where there is a "mixed economy of welfare" (Powell, 2007) and where legislation, social policy and services for young carers are relatively "advanced" (Becker, 2007). Children caring for parents with HIV in the UK represent a hidden group, while in Tanzania and other Eastern and Southern African countries, it is a much more frequent occurrence. Evans' previous research experience with children and families affected by HIV, and Kiswahili language proficiency gained through her work in northern Tanzania, largely determined the choice of Tanzania as one of the countries for the study.

We specifically chose to conduct the Tanzanian research first in order to ensure our understanding of how children's resilience is fostered in a resource-constrained setting informed our approach to young caregiving and HIV in the UK. Given the hidden situation of young carers, the importance of confidentiality and the need to minimise the risk of disclosure of participants' HIV status ${ }^{4}$, qualitative methods were considered most appropriate. We designed information leaflets, interview schedules and a life-story book for children to complete with no mention of HIV to protect participants' status. These were translated into Kiswahili with research assistance. The use of the same semi-structured interview schedules for use in both countries, albeit conducted in Kiswahili in Tanzania and English in the UK, facilitated cross-national analyses of the data and the development of comparative understandings, while allowing flexibility to tailor questions to the specific context. Audio-recorded interviews conducted in Kiswahili were transcribed into English with research assistance to facilitate comparative analyses.

Despite using the same research instruments in both countries, differences were evident in the ways that young people engaged with participatory methods. "Task-centred activities" are often viewed as enabling children to have more control over the representation of their lives (Christiansen and James, 2000). Young people (aged 12 to 19 years) in Tanzania particularly engaged with the life-story book and photovoice methods, enjoying the opportunity to write, draw pictures and take photographs. Children aged under 12 in Tanzania, who had often only attended primary school for a few years and had disrupted schooling due to their care work and poverty, found it more difficult to complete the life-story book and on occasion, asked older siblings or their parent to help them write. In contrast in the UK, teenagers preferred to participate using photovoice, taking photographs of their care work and people and places that were important to them, which were discussed during an interview. However, some young people (of varying ages) in the UK preferred to "just talk", perceiving the life-story book and photovoice method as extra "homework" and a demand on their time. This serves as an important reminder of the diverse ways that young people may engage with research; flexibility is needed to tailor qualitative methods to particular research settings and children's preferences and competencies, with an awareness of the competing demands on young carers' time.

In Tanzania, ethical tensions were evident in relation to Evans' position as a White British researcher from an affluent country conducting cross-cultural research in a Majority world 
country. The legacy of colonialism and global inequalities mean that White people who travel or live in Tanzania are much more wealthy than the average Tanzanian. Despite efforts to manage participants' expectations, some parents and children in Tanzania inevitably saw Evans as a potential source of financial support. Project workers in Tanzania often asked what we were planning to do to help the families who had participated in the study, raising difficult ethical questions common in cross-cultural research with families experiencing chronic poverty (Evans, 2016). On reflection, we could have done more to ensure the findings were shared and discussed with policymakers and practitioners working at strategic/ national levels in order to increase the potential of the research to achieve sustained social impacts (see Evans, 2017).

Owing to the smaller population of HIV-affected families in the UK, stigma and concerns about confidentiality, negotiating access to children and parents in the UK was a more complicated and time-consuming process. This resulted in a smaller sample of families (14 households) in comparison with those interviewed in Tanzania ( 24 households). A few young people in the UK who originally agreed to participate decided to withdraw before meeting the researcher. Project workers suggested their reasons for withdrawal were related to not wanting to talk about sensitive issues, as Cree et al. (2002) found. Parents were particularly concerned about confidentiality and anonymity, both of the tape-recorded interviews and written outputs of the research.

The differing HIV prevalence in each country, in addition to differences in ethnicity, immigration status and living arrangements resulted in a diverse purposive sample. Over a third of households in Tanzania were extended families, as is common in Tanzania and other African countries, and there was one youth-headed household. Given child protection legislation, greater availability of formal welfare support and lower prevalence of AIDSrelated orphanhood, the formation of youth-headed households is much less likely in the UK (no reliable numbers are available). In Tanzania, participants were recruited from the majority population living in rural and urban areas and included a range of ethnic groups. Most UK families (11 out of 14) were African migrants living in London or other cities in England and were of black African ethnicity, with two of white British and one of Asian British ethnicity. The majority of African migrants had been granted Indefinite Leave to Remain or British citizenship, while three were seeking asylum or had insecure immigration status. This reflects the dynamics of the HIV epidemic in England, where African families are disproportionately affected by HIV compared with white British families (UK Collaborative Group for HIV and STI Surveillance, 2006). Over a quarter of the households in the UK were transnational families, comprised of a parent and their younger children living in the UK, while other family members remained in their country of origin.

Despite these differences in family dynamics and migration experiences in Tanzanian and the UK, there were also striking similarities. In both countries, the majority of families were oneparent households and the majority of young people interviewed were children (aged 9-17) who were caring for their mother with HIV and sometimes also siblings with HIV , as Bauman et al (2006) also found. Project workers identified very few young people caring for fathers living with HIV, which may be linked to female partners or relatives being more likely to care for men than children. Men may also be less open about their HIV status and reluctant to be involved in research studies focusing on health issues, children and families. African men in the UK are often considered isolated and less willing to talk about their experiences of HIV than African women (Doyal et al, 2005; Ridge et al, 2008). 
Young people generally started caring for their parent/relative when they were 10 years old or older, with a mean age (based on children's accounts) of 12 and 11 years old in Tanzania and the UK respectively. The majority of young carers were girls (23 out of 33 or $70 \%$ of the sample), which was particularly evident in the UK ( 9 out of 11 children) and among the young adult carers (aged 18-24) in Tanzania (8 out of 9). In Tanzania, almost as many younger (aged 9-17) boys (7) as girls (8) were carers compared to girls in the same age group, defying assumptions that care work is always gendered as "women's and girls' work".

Having explored some of the ethical tensions and comparisons in family dynamics and caring situations in our study, we next reflect on how understandings gained in the Majority world can help to further global conceptualisations of children's care work.

\section{Conceptualising children's care work globally}

Commentators have drawn attention to the cultural specificity of conceptual frameworks often developed in Minority European socio-linguistic contexts and call for greater engagement with theoretical, empirical and methodological insights gained in the Majority world (Evans et al, 2017; Ribbens McCarthy et al, 2017; Punch, 2016). In our comparative study, we sought to reflect on the usefulness of framings of young caregiving developed hitherto primarily in Minority world contexts.

\section{Continuum of young caregiving}

When developing our comparative analyses, we drew on Becker's (2007) continuum of care, along which all children's informal caring can be located, to conceptualise the level of involvement and outcomes ${ }^{5}$ of children's care work. Becker (2007, p.32) argues that, "Some children are drawn into substantial, regular and significant caring roles and Instrumental Activities of Daily Living irrespective of the degree of social development or the sophistication of the welfare regime or welfare mix that characterizes the country in which they live". Young carers would be placed at the "heavier", more substantial and regular caregiving end of the continuum, which includes Activities of Daily Living (such as assisting relatives with mobility and providing personal care) and many would also be doing a significant amount of tasks associated with Instrumental Activities of Daily Living (household chores) (Morrow, 2005). Their care work is thus distinguished in terms of the extent, nature and outcomes of their caring from that of other children (Becker, 2007).

In view of our findings, we suggested that some modifications to the continuum were necessary. The changing nature of HIV-related chronic illness, care needs and varying access to external support highlighted the fact that children's caring roles are not static. We therefore argued for a more dynamic and fluid understanding of children's positioning on the continuum over time and place. Children's levels of care work shift, depending on fluctuations in a parent's health, as well as a parent's/relative's requirement for assistance and their access to informal and formal safety nets that can alleviate children's caring responsibilities (Evans and Becker, 2009). Furthermore, young people may care for several different family members with a range of impairments and care needs over time (Evans, 2010).

The revised continuum (see Figure 1) includes arrows pointing in both directions to indicate how children may move both ways along the continuum, towards lower levels of caregiving and responsibility, as well as towards higher levels. It is not inevitable that children's care 
work will increase in intensity over time; if children are provided with appropriate support, their care work may decrease, with reduced negative outcomes for their wellbeing.

\section{INSERT FIGURE 1 HERE}

Our study also highlighted the importance of understanding cultural norms of age, gender and generational relations within specific contexts, which is acknowledged in the revised continuum.

\section{Children's caring activities}

Our research in Tanzania and the UK revealed that children's caring activities for parents with HIV were broadly similar and differed significantly from the usual household responsibilities of most children in that cultural context (Evans and Becker, 2009). Despite these commonalities, children's care work in the UK and Tanzania did differ in the intensity and time taken to perform household chores and caring tasks because of disparities in living standards between Majority and Minority worlds. As Ogden et al, (2006) note, domestic chores are likely to be particularly time-consuming and require additional resources in households affected by chronic illness or disability in the Majority world, especially in rural areas, which are often compounded by a lack of basic services such as clean water and electricity. Children's care work in Tanzania took longer and was more physically demanding than in the UK; in Tanzania, washing clothes and bed sheets, for example, needed to be done by hand, water needed to be fetched and so on, compared to using a washing machine in the UK.

Based on the findings of our Tanzania-UK study, in addition to Evans' subsequent research on sibling caregiving in child- and youth-headed households in Tanzania and Uganda (Evans, 2012), a categorisation of the caring activities that children are involved in globally can be developed. Table 1 (below) shows the wide range of caring activities young people may be involved in, with examples drawn predominantly from African contexts. This illustrates how Majority world understandings are useful in conceptualising children's care work globally. The particular activities vary in different cultural, socio-economic and welfare contexts and through time, thus the examples given should be seen as illustrative only.

\section{INSERT TABLE 1 HERE}

While most of these categories of caring tasks were evidenced in our Tanzania-UK study, we did not specifically identify self-care, household management or community engagement activities. In her research on sibling caregiving, Evans (2012) found the term "self care" useful in categorising a range of individual, embodied activities for which children are usually expected to take increasing responsibility as they grow older, but which in the absence of adult caregivers, they may perform without adult support or guidance. The category is also relevant when parents/adult relatives may not be able to fulfill their usual parenting roles due to mental health and/or drug or alcohol use problems. Little research to date has investigated children's care work in these contexts in the Majority world ${ }^{6}$.

Income earning activities emerged as an important difference between children's caring responsibilities in the Majority and Minority worlds (Evans and Becker, 2009). Many children in Tanzania combined their care work with paid work to compensate to some extent 
for the loss of the parent's income-earning capacity. Although several young people in the UK had part-time jobs, they were not under the same financial pressures as were the young people in Tanzania to earn money to pay for basic necessities such as food. While many children living in poor households are likely to engage in some form of paid work in the Majority world, and this category is not usually regarded as "unpaid care work" in time-use surveys (Budlender, 2010), casual labour and work in the informal sector represents a key element of children's care work in households affected by HIV, because children seek to replace household income lost through a parent's/ adult relative's illness, impairment or death.

Managing the household and making decisions were crucial dimensions of the care work of young people caring for siblings independently (Evans, 2012). Household management tasks are likely to be a less significant aspect of care work for children caring for parents/adult relatives, since disabled parents/adult relatives usually retain their position of power within the household and are responsible for making decisions, budgeting and so on, in accordance with wider generational norms and age hierarchies, and in spite of their illness or impairment (Robson et al., 2006; Evans and Becker, 2009).

Given the importance of young people's social networks and access to informal and formal resources in sustaining households affected by chronic illness and disability, the category of community engagement can also be considered a key dimension of young people's care work in the Majority world. Young people caring for siblings in Uganda and Tanzania confirmed the relevance of this dimension of their care work (Evans, 2012). This category is also relevant to children caring for parents with HIV in Tanzania, given the importance of informal support and limited formal safety nets (Evans and Becker, 2009). This category thus appears relevant to children caring in a range of situations in the Majority world.

\section{Risk and protective processes}

The analytic framework developed by Becker et al. (1998) identified the nature of the illness/disability, family structure, gender and co-residence, status and power and the availability and nature of external support as factors that "push" or "pull" some children into unpaid caring roles in a household. Robson's (2004) research in Zimbabwe and our study confirmed that these factors were salient in Eastern and Southern African contexts. Both studies also sought to relate children's care work at the micro-level to broader processes of global economic restructuring, the HIV epidemic, and policies that 'download responsibility for care’ onto women, children, families and communities (Ogden et al., 2006, p.333).

In our study, the fact that the majority of the UK sample of families affected by HIV were African migrants with varying immigration statuses and differential access to health and social care support added an extra dimension of complexity to our comparative analyses. However, the understanding of young caregiving and family dynamics gained in an East African context helped to shape our analyses of care among African migrants in the UK. Commonalities in constructions of care, gender and generational norms and family dynamics were evident among Eastern and Southern African migrant and Tanzanian families, enabling exploration of the interaction between "African" and "British" expectations of young carers (see Evans, 2011). For example, children's roles as "carers" appeared to subvert idealised notions of childhood that were associated more with "British" rather than "African" values. Yet most mothers in both countries, but especially in the UK, regretted their children's caring responsibilities and related their need for care to a lack of alternative support rather than 
African cultural norms about children's contributions to the family. Furthermore, caring relationships and the mobility of African migrant families at the local level were influenced by wider global processes such as global inequalities in access to HIV treatment between the Minority and Majority worlds, restrictive immigration policies and the emotional and material demands of maintaining transnational ties to family members "back home" (Evans, 2011).

Given this complexity, we sought to highlight the range of individual, relational and structural processes that may influence whether children take on caring roles, and the level of their involvement in care in families affected by HIV across Majority-Minority worlds. In the nexus of risk and protective processes we developed (Evans and Becker, 2009, p.229), global forces identified at the macro-scale include: economic liberalisation; transnational migration; the prevalence of impairment; health inequalities; epidemics such as HIV (and more recently Ebola); international development goals and priorities for donor aid; global and national welfare regimes; legislative frameworks; interventions to support children and families, caregivers and disabled people and facilitate their participation in decision-making processes. The macro-environment of young caregiving is also structured by socio-cultural beliefs and values such as gender norms and constructions of care and childhood.

At the community level, the availability of formal and informal safety nets significantly influences whether children take on caring roles and can potentially alleviate or increase the extent of their care work. Micro-level factors such as the parent/relative's health, disclosure of their health status/ impairment, poverty and changes in household structure, as well as individual differences among children, such as gender, age and sibling birth order, the quality of their relationship with the parent/relative they care for, personal attributes and co-residence are likely to have significant influences on whether children take on caring roles, the extent of their care work and outcomes for children's wellbeing.

Thus, the particular risk and protective factors influencing whether children take on caring roles and the level of their involvement depends on the complex interaction between these processes from the macro to the micro scales, whether children live in a Majority or Minority world country. Young people negotiate their caring trajectories within both the constraints and the possibilities of this global nexus and may embrace or resist the responsibilities and expectations placed on them over time (Evans and Becker, 2009).

This section has demonstrated that understandings of children's care work gained in Eastern and Southern Africa and in migration contexts have much to contribute to global conceptualisations of children's care work. Defining "young carers" in Majority world contexts is however fraught with tensions, as we explore in the next section.

\section{Defining "young carers" globally}

While few other studies of "young carers" have explicitly adopted a comparative focus across Majority-Minority worlds, a growing literature is providing evidence about children's everyday social reproductive work and caring roles in response to a diverse range of care needs in the Majority world (Abebe and Kjørholt, 2009; Day and Evans, 2015; Evans, 2014b; Dahlblom, 2008; Payne, 2012; Punch, 2001; Skovdal and Evans, 2016). Some studies focus on young migrant children's care work for family members in the Minority world (Diaz et al, 2007; Evans, 2011). Researchers' and practitioners' efforts to share learning across worlds in workshops and symposia has enabled dialogue to develop across Majority-Minority binaries. 
However, these endeavours have revealed a number of tensions when using the term, "young carers". Indeed, Evans and Skovdal (2015) suggest a lack of clarity when categorising "young carers", and drawing a line between "appropriate" or "inappropriate" caregiving, may explain why so little has been done to support caregiving children in Sub-Saharan Africa.

Policy and practice responses to children affected by the HIV epidemic have been dominated by a focus on the category of "orphaned and vulnerable children" (OVC). Meintjes and Giese (2006) argue that despite this more inclusive rhetoric, most policy interventions in Africa have remained "orphan-centred" and paid little attention to other children who may be just as vulnerable. Alongside OVC discourse in response to the HIV epidemic, the predominant focus of international policy and NGO action in Majority world contexts has been on abolishing children's paid work, underpinned by dominant rights discourses. This agenda may hinder the development of support services for young carers, as Skovdal et al (2013) found in Kenya. In a workshop in Nairobi in 2011, policymakers expressed concerns that providing support for "caregiving children" could be seen as an endorsement of child labour. Such apprehensions may encourage practitioners to adopt a more clear-cut abolitionist approach to children's work (whether paid or unpaid) and to focus only on the prevention of young caregiving. This may hinder the development of support services for the many children who are already providing care in communities affected by HIV in Eastern and Southern Africa (Evans and Skovdal, 2015). This approach contrasts with the situation found in the UK and Australia where support services for young carers are primarily focused on "mitigating" or alleviating their care work to some extent, rather than on prevention and early intervention (Purcal et al, 2012). Furthermore, holistic whole family approaches, which include aspects of prevention, early intervention and mitigation, have long been advocated by third sector organisations such as the Children's Society in the UK (Frank and McLarnon, 2008).

Although the terminology may be problematic, the potential advantages for some children of being specifically identified as "young carers" include recognising children's significant unpaid care work; facilitating access to community-based interventions; fostering opportunities for peer support; and linking with advocacy and lobbying around the needs and rights of young carers nationally and globally (Evans and Becker, 2009). In the UK, for example, it conveys specific legal rights to assessments and support (Leu and Becker, 2017). Given the stigma attached to the term "orphan" in many African societies (Meintjes and Giese, 2006), the term "young carer" may offer a more positive label that recognises young people's active roles in contributing to their families and communities. In view of these potential benefits, Evans and Skovdal (2015) proposed a modified version of Becker's (2000) original definition of "young carers", which recognizes the cultural specificities of familial and communal responsibilities and care needs in Majority world contexts:

Young carers can be defined as children and young persons under 18 who provide or intend to provide care, assistance or support for a relative or community member. They carry out, often on a regular basis, significant or substantial caring tasks and assume a level of responsibility that would usually be associated with an adult in particular cultural contexts. The person receiving care may be a parent, sibling, grandparent, other relative or community member who has a need for care, support or supervision which is related to an impairment, chronic illness, mental health problem or other condition. The need for care may also be related to a sibling's/ relative's/ neighbour's young or old age and competencies. (adapted from Becker 2000, p. 378; Evans and Skovdal, 2015, p.9) 
Becker's (2000) original definition focused on care needs in relation to impairments and did not encompass care needs related to young or old age. The more inclusive definition above includes sibling caregiving in child- and youth-headed households (where children care for their siblings and manage the household independently without a co-present adult relative: Evans, 2012), as well as children's care work for older people in the community, who may not live in the children's own households or be relatives (Skovdal, 2011). Research in other Majority world contexts is likely to reveal other diverse situations in which children provide care, which may help to inform global definitions and conceptualisations of young caregiving in future and facilitate dialogue on children's commonalities and differences across worlds.

While the term "child carers" appears to be used more commonly than "young carers" in some literature in relation to African/ Majority world contexts (Bray, 2009; Becker, 2007), the term "caregiving children" proposed by Skovdal and Andreouli (2011) may be preferable. This term emphasises children's agency and their social position as children rather than assuming they necessarily identify as carers. The use of children (plural) rather than child (singular) also implies diversity among children's experiences and recognition of intersecting social differences of gender, age, ethnicity and so on (Twum-Danso Imoh, 2016).

Nevertheless, in Minority world contexts, "young carers"/"young caregivers" remains the most commonly used term in research, legislation, social policy and support and often links with advocacy work on (adult) carers' rights (Becker, 2007). We suggest that clarity about the terms used and critical reflection on the situatedness of global definitions and conceptualisations is needed, given the wider dominance of Minority world perspectives and framings in the social sciences.

\section{Conclusion}

This chapter has explored methodological, ethical and conceptual challenges posed by research on children's care work that crosses Majority-Minority world binaries. Our comparative study in Tanzania and the UK sought to shape global understandings of children's care work informed by both Majority and Minority world experiences. The research highlighted the need to analyse broader macro-scale global forces, structural inequalities and cultural norms that influence children's caring roles and outcomes, alongside analysis of micro-scale individual experiences and household factors. Our analysis supports Ansell's (2009) call for greater attention to be paid to the policies and discourses that affect children, and to adults who are involved in constructing these, rather than only researching with children.

Several tensions surround the use of the terminology of "young carers" in African contexts, and probably elsewhere in the Majority world, not least the dominance of discourses and interventions focused on child labour, children's rights, and orphaned and vulnerable children. While the term "caregiving children" may help to emphasise children's agency and diversity, there are benefits to specifically recognising children's caring roles as "young carers/ young caregivers" through linking with Minority world research and advocacy. Evans and Skovdal's (2015) more inclusive definition recognises the diverse caring roles that children may undertake in Majority world settings, including responding to care needs related to young and old age. Given the dominance of anglophone Minority world theorising and publishing within the social sciences, it is crucial to critically reflect on the appropriateness of terminology, conceptual framings and approaches to children's care work within Majority world contexts. 
Within an increasingly interdependent globalised world, comparative research and dialogue between researchers, policymakers, practitioners and young people across Majority-Minority binaries seems ever more important. Global processes of migration and the HIV epidemic, in particular, provide unique opportunities to explore the commonalities and diversities in children's caring lives across diverging socio-economic, cultural and political contexts. Working across geographical, linguistic and disciplinary boundaries will help to develop robust evidence that can inform global policy, development interventions and services to support this often invisible group of children and their families and communities.

\section{Endnotes}

1. This chapter is a synthesis and revised version of some arguments originally developed in Evans and Becker (2009), Evans (2010; 2014a) and Evans and Skovdal (2015).

2. The terms "Minority" and "Majority" worlds are used in preference to the terms, "global North" and "global South" respectively, to highlight the fact that affluent societies in Europe, North America, Australia and so on comprise the minority of the world's population, land mass and so on, while the majority of the world's population, land mass and so on are located in low and middle-income countries.

3. The research was funded by the Economic and Social Research Council, UK 2006-2007, grant number RES-000-22-1732-A. See Evans and Becker (2009) for discussion of the findings in global perspective.

4. Ethical approval for the study was granted by the Research Ethics Committee, University of Birmingham and the National Institute for Medical Research, Tanzania. Authorisation for the research was granted by the Tanzania Commission for Science and Technology and the University of Dar es Salaam.

5. Space does not permit discussion of the outcomes of children's care work here. See Evans and Becker (2009), Evans (2010), Bray (2009), Skovdal and Andreouli (2011).

6. Payne's (2012) study in Zambia included some children living with a parent with alcohol use problems.

\section{References}

Abebe, T. and Kjørholt, A. T.(2009). Social actors and victims of exploitation. Working children in the cash economy of Ethiopia's South. Childhood, 16(2),175-194.

Andreouli, E., Skovdal, M., and Campbell, C.(2013). "It made me realise that I am lucky for what I got": British young carers encountering the realities of their African peers. Journal of Youth Studies, 16(8),1038-1053. DOI:10.1080/13676261.2013.772574

Ansell, N.(2009). Childhood and the politics of scale: descaling children's geographies? Progress in Human Geography, 33(2),190-209, DOI: 10.1177/0309132508090980.

Bauman, L., Foster, G., Johnson Silver, E., Gamble, I. and Muchaneta, L.(2006). Children caring for their ill parents with HIV/AIDS. Vulnerable Children and Youth Studies, $1(1), 1-14$ 
Becker, S.(2000). Young carers. In Davies, M., (ed.) The Blackwell Encyclopedia of Social Work. Oxford: Blackwell, p 378.

Becker, S.(2007). Global perspectives on children's unpaid caregiving in the family: research and policy on 'young carers' in the UK, Australia, the USA and Sub- Saharan Africa. Global Social Policy, 7(1),23-50.

Becker, S., Aldridge, J. and Dearden, C.(1998). Young Carers and Their Families. Oxford: Blackwell Science.

Boyden, J.(1997). Childhood and the Policy Makers: A Comparative Perspective on the Globalization of Childhood. In A. James and A. Prout, Constructing and Reconstructing Childhood, London: Falmer Press, pp.190-229.

Bray, R.(2009). A Literature Review on Child Carers in Angola, Nigeria, Uganda and Zimbabwe. Unpublished report. London: Save the Children UK.

Budlender, D.(2010). What do time use studies tell us about unpaid care work? Evidence from seven countries. In: Budlender, D. (Ed.), Time Use Studies and Unpaid Care Work. Routledge, London and New York, pp. 1-46.

Christensen, P. and James, A.(2000). Research with Children: Perspectives and Practices, London: Falmer Press.

Cluver, L., Operario, D., Lane, T., and Kganakga, M.(2012). "I Can't Go to school and leave her in So much pain": Educational shortfalls among adolescent "young carers" in the South African AIDS epidemic. Journal of Adolescent Research, 27(5),581-605. doi:10.1177/0743558411417868.

Cree V., Kay, H., Tisdall, E., and Wallace, J.(2006). Listening to children and young people affected by parental HIV: findings from a Scottish study. AIDS Care, 18(1), 73-76.

Dahlblom, K.(2008). Home alone. Sibling caretakers in Léon, Nicaragua. Medical Dissertation No. 1210, Department of Public Health and Clinical Medicine, Medical Faculty, Umeå University, Sweden.

Day, C. and Evans, R.(2015). Caring responsibilities, change and transitions in young people's family lives in Zambia.Journal of Comparative Family Studies, XLVI (1), 137-152.

Diaz, N., Siskowski, C. and Connors, L.(2007). Latino young caregivers in the United States: who are they and what are the academic implications of this role? Child Youth Care Forum, 36, 131-140.

Doyal L, Anderson J, Apenteng P.(2005). "I want to survive, I want to win, I want tomorrow": An exploratory study of African men living with HIV in London. Homerton University Hospital and Terrence Higgins Trust: London. 
Evans, R. (2010).Children's caring roles and responsibilities within the family in Africa. Geography Compass, 4(10),1477-1496

Evans, R. (2011).Young caregiving and HIV in the UK: caring relationships and mobilities in African migrant families. Population, Space \& Place, 17(4),338-360.

Evans, R. (2012). Sibling caringscapes: time-space practices of caring within youth-headed households in Tanzania and Uganda. Geoforum, 43, 824-835.

Evans, R.(2014a). Children as caregivers. In A. Ben-Arieh, F. Casas, I. Frones and J. E. Korbin (eds.) Handbook of Child Well-Being. Dordrecht: Springer.

Evans, R.(2014b). Parental death as a vital conjuncture? Intergenerational care and responsibility following bereavement in Senegal. Social and Cultural Geography, 15(5),547-570.

Evans, R.(2016). Achieving and evidencing research 'impact'? Tensions and dilemmas from an ethic of care perspective. Area, 48(2),213-221. doi:\%2010.1111/area.12256.

Evans, R.(2017). Critical reflections on participatory dissemination: Co-producing research messages with young people. In Evans, R. and Holt, L. (eds) Methodological Approaches. Geographies of Children and Young People, Vol.2, Springer major reference work (Editor-in-Chief: Tracey Skelton), pp.67-96.

Evans, R. and Becker, S.(2009). Children Caring for Parents with HIV and AIDS: Global Issues and Policy Responses. The Policy Press: Bristol.

Evans, R. and Skovdal, M.(2015). Defining children's rights to work and care in Sub-Saharan Africa: tensions and challenges in policy and practice. In Kallio, K. P. and Mills, S. (eds.) Politics, Citizenship and Rights, Vol. 7 of Skelton, T. (ed.) Geographies of Children and Young People. Springer: Singapore.

Evans, R. Ribbens McCarthy, J., Kébé, F., Bowlby, S., and Wouango, J.(2017). Interpreting 'grief' in Senegal: language, emotions and cross-cultural translation in a francophone African context. Mortality, 22(2),118-135.

Frank, J. and McLarnon, J.(2008). Young Carers, Parents and their Families: Key Principles of Practice. London: The Children's Society.

ILO.(2014). Convention concerning Minimum Age for Admission to Employment C138 Minimum Age Convention, 1973 (No.138). Available at http://www.ilo.org/dyn/normlex/en/f?p=NORMLEXPUB:12100:0::NO::P12100_ILO CODE:C138

Leu, A. and Becker, S.(2017). A cross-national and comparative classification of in-country awareness and policy responses to "young carers". Journal of Youth Studies, 20(6), 750-762 DOI:10.1080/13676261.2016.1260698 
Meintjes, H. and Giese, S.(2006). Spinning the epidemic: the making of mythologies of orphanhood in the context of AIDS. Childhood, 13(3),407-430.

Morrow, R. (2005). A Profile of Known Young Carers and Identification and Snapshot of the Ones Who are Hidden. Perth: Curtin University of Technology.

National Alliance for Caregiving in collaboration with the United Hospital Fund (2005). Young Caregivers in the U.S.: Report of Findings September 2005. Bethesda: NAC. Available at www.caregiving.org and www.uhfnyc.org.

Ogden, J., Esim, S., and Grown, C.(2006). Expanding the care continuum for HIV/AIDS: bringing carers into focus. Health Policy and Planning 21(5),333-42.

Payne, R. (2012). "Extraordinary survivors" or "ordinary lives"? Embracing "everyday agency" in social interventions with child-headed households in Zambia. Children's Geographies, 10, 399-411.

Powell, M (ed.) (2007). Understanding the Mixed Economy of Welfare, Bristol: The Policy Press.

Punch, S. (2001). Household division of labour: generation, gender, age, birth order and sibling composition. Work, Employment and Society 15(4), 803-23.

Punch, S.(2016).Cross-world and Cross-disciplinary Dialogue: A More Integrated, Global Approach to Childhood Studies. Global Studies of Childhood, 6(3),352-364.

Purcal, C. Hamilton, M., Thomson, C. and Cass, B.(2012). From Assistance to Prevention: Categorizing young carer support services in Australia and international implications. Social Policy and Administration, 46(7),788-806.

Ribbens McCarthy, J., Guo Yu, Phoenix, A.; Xu Xiaoli, and Knight, A.(2017). The institutionalisation of "TongNian" and "childhood" in China and Britain: exploring cautious comparisons. Childhood and Society, 31(1), 1-12. https://doi.org/10.1111/chso.12166.

Ridge D, Williams A., Anderson, J., Elford, J.(2008). Like a prayer: the role of spirituality and religion for people living with HIV in the UK. Sociology of Health and illness $30(3), 413-428$.

Robson, E.(2004). Hidden child workers: young carers in Zimbabwe. Antipode 36(2),227-48.

Robson, E. and Ansell, N.(2000). Young carers in Southern Africa: exploring stories from Zimbabwean secondary school students. In Holloway, S. \& Valentine, G., (Eds.), Children's Geographies, pp.174-93. London and New York: Routledge.

Robson, E., Ansell, N., Huber, U.S., Gould, W. T. S. and van Blerk, L.(2006). Young caregivers in the context of the HIV/AIDS pandemic in sub-Saharan Africa. Population, Space and Place, 12,93-111. 
Skovdal, M.(2011). Examining the trajectories of children providing care for adults in rural Kenya: implications for service delivery. Children and Youth Services Review 33, 1262-1269.

Skovdal, M and Andreouli, E.(2011). Using identity and recognition as a framework to understand and promote the resilience of caregiving children in Western Kenya. Journal of Social Policy, 40(3),613-630.

Skovdal, M. and Evans, R.(2017). The emergence of an ethic of care in rural Kenyan schools? Perspectives of teachers and orphaned and vulnerable pupils. Children's Geographies, 15(2),160-176.

Skovdal, M., Campbell, C., and Onyango, V.(2013). Supporting 'young Carers' in Kenya: From policy paralysis to action. Child Care in Practice, 19(4),318-339.

Twum-Danso Imoh, A.(2016). From the singular to the plural: exploring diversities in contemporary childhoods in sub-Saharan Africa. Childhood, 23(3),455-468.

UK Collaborative Group for HIV and STI Surveillance.(2006). A Complex Picture. HIV and other Sexually Transmitted Infections in the United Kingdom: 2006, Health Protection Agency, Centre for Infections: London. 


\section{Evans and Becker's chapter: Comparing Children's Care work across Majority and Minority worlds}

Table 1: Categories of children's and young people's caring activities globally, with examples from Majority world contexts (adapted from Evans, 2010; 2014a). Reprinted by permission from Springer Nature: Children as Caregivers, in Handbook of Child Well-Being edited by A. Ben-Arieh, F. Casas, I. Frones and J. E. Korbin (2014).

\begin{tabular}{|c|c|}
\hline Caring activity & Examples \\
\hline $\begin{array}{l}\text { Household } \\
\text { chores }\end{array}$ & $\begin{array}{l}\text { Cooking, washing dishes, sweeping, cleaning and tidying, fetching water and firewood, } \\
\text { laundry, heating water for baths, shopping, cultivating food for consumption, tending } \\
\text { livestock, cutting wood, running errands }\end{array}$ \\
\hline Health care & $\begin{array}{l}\text { Reminding parent/sibling/ relative to take medication, giving and collecting medication, } \\
\text { accompanying them to hospital and providing care while in hospital, assisting with } \\
\text { mobility, preparing special nutritional food, cleaning, treating and dressing sores, } \\
\text { infections and wounds, massaging the body }\end{array}$ \\
\hline Personal care & Washing/bathing parent/relative, assisting to eat, dress and use the toilet \\
\hline Child care & $\begin{array}{l}\text { Getting siblings ready for school, bathing siblings, supervision, resolving arguments and } \\
\text { conflict between siblings, help with school work }\end{array}$ \\
\hline $\begin{array}{l}\text { Emotional } \\
\text { support }\end{array}$ & $\begin{array}{l}\text { Talking and comforting parent/sibling/ relative, giving advice and guidance, 'being there' } \\
\text { for them }\end{array}$ \\
\hline Self care & $\begin{array}{l}\text { Personal care of self, taking medication, getting ready for school, private study, personal } \\
\text { development, training, developing life skills and livelihood strategies etc. }\end{array}$ \\
\hline $\begin{array}{l}\text { Income-earning } \\
\text { activities }\end{array}$ & $\begin{array}{l}\text { Cultivating crops and produce for sale, rearing livestock, casual agricultural and } \\
\text { construction work, fishing, working in a factory, shop or bar, selling produce, cooked } \\
\text { food, charcoal and other goods, domestic work, running errands for neighbours, begging }\end{array}$ \\
\hline $\begin{array}{l}\text { Household } \\
\text { management }\end{array}$ & $\begin{array}{l}\text { Allocating tasks, paying school contributions, organising school/vocational training, } \\
\text { reminding parent/sibling/relative about appointments, paying bills and resolving financial } \\
\text { problems, budgeting, future planning and decision-making }\end{array}$ \\
\hline $\begin{array}{l}\text { Community } \\
\text { engagement }\end{array}$ & $\begin{array}{l}\text { Maintaining social networks, seeking support from and cooperating with relatives, } \\
\text { neighbours, friends, NGOs, members of faith community, participating in neighbourhood, } \\
\text { school, faith community, youth and NGO meetings, activities, celebrations and events. }\end{array}$ \\
\hline
\end{tabular}




\section{Evans and Becker's chapter: Comparing Children's Care work across Majority and Minority worlds}

Figure 1: A continuum of young caregiving (Evans, 2014a, p.1896; adapted from Evans, 2010; Evans and Becker, 2009; Becker, 2007). Reprinted by permission from Springer Nature: Children as Caregivers, in Handbook of Child Well-Being edited by A. Ben-Arieh, F. Casas, I. Frones and J. E. Korbin (2014).

\begin{tabular}{|c|c|c|}
\hline $\begin{array}{c}\text { Low levels of caregiving } \\
\text { and responsibility }\end{array}$ & $\begin{array}{c}\text { High levels of caregiving and } \\
\text { responsibility }\end{array}$ \\
\hline 'Caring about' & & 'Caring for' \\
\hline Most children and young \\
people
\end{tabular}




\section{Evans and Becker's chapter: Comparing Children's Care work across Majority and Minority worlds}

\section{Acknowledgements}

We would like to thank all the participants of the Tanzania-UK study discussed here, Morten Skovdal for helpful discussions and reflections, and the editors for their useful feedback on an earlier version of this chapter.

\section{Biographies}

Ruth Evans is an Associate Professor in Human Geography at the University of Reading, UK. Her research focuses on young people's psychosocial wellbeing, young caregiving and family relations in relation to bereavement, chronic illness and forced migration. Recent work has also explored emotions in research, participatory methodologies and social impact. Her research project, Death in the family in urban Senegal: bereavement, care and family relations (funded by The Leverhulme Trust) explored gendered and generational caring relations following a family death. She is co-author of Children Caring for Parents with HIV and AIDS: Global Issues and Policy Responses (with Saul Becker, The Policy Press). Journal articles have discussed sibling caringscapes (Geoforum) and care ethics in families affected by HIV (with Felicity Thomas, Emotions, Space \& Society), in school environments (with Morten Skovdal, Children's Geographies) and in interactions between professionals and disabled forced migrants (with Gudbjorg Ottosdottir, British Journal of Social Work).

Saul Becker is Deputy Vice Chancellor at the University of Sussex and Professor of Social Policy and Social Work. He has researched and published extensively on young carers in the UK and internationally. He is co-author of Children Caring for Parents with HIV and AIDS: Global Issues and Policy Responses (with Ruth Evans, The Policy Press) and many other publications examining specific aspects of children's caring roles and responsibilities. His latest research collaboration is a Horizon 2020 project examining the mental health needs of young adult carers in seven European countries. 